\title{
BERHIKMAT DALAM BERTEKNOLOGI KHUSUSNYA BAGI ANAK-ANAK DIMASA PANDEMI SAAT INI
}

\author{
Melianti Kiding Allo \\ Lembaga :IAKN Toraja,posel:@meliantikidingallo
}

\section{Abctrak :}

Currently the development of children is the center of attention for families and schools, where at this time technology or social media in the current digital era has a very good and bad impact on children if parents and teachers do not monitor children in using social media. the impact of the misuse of technology, it must continue to guide children. Education in schools is very helpful for the growth and development of children. Because children who receive education at school understand more about some of the things that can be learned at school and children's behavior is more functional because it is shaped by observation and influenced by what they get. When parents or teachers educate children well, the child's association will be better. Because nowadays, especially the use of technology or social media, it really has an impact on children.

Abstrak :

Saat ini perkembangan anak-anak menjadi pusat perhatian bagi keluarga dan sekolah,dimana pada saat ini teknologi atau media social pada erah digital saat ini sangat memberi dampak baik buruknya kepada anak apabila orang tua dan guru tidak memantau anak dalam menggunakan media social tersebut.Ada banyak dampak yang ditimbulkan dari penyalagunaan teknologi, maka harus tetap membimbing anak ${ }^{1}$. Pendidikan disekolah sangat membantu pertumbuhan perkembangan anak. Karena anak yang mendapat Pendidikan di sekolah lebih mengerti tentang sebagian hal-hal yang di dapat di sekolah dan perilaku anak lebih banyak berfungsi karena karena di bentuk oleh pengamatan dan di pengaruhi dengan apa yang mereka dapatkan. Ketika orang tua atau guru mendidik anak dengan baik maka pergaulan anak akan lebih baik. Karena dimasa sekarang ini khususnya penggunaan teknologi atau media sososil sangat membawa dampak bagi anak. ${ }^{2}$

\footnotetext{
${ }^{1}$ Https://www.scribd.com/document/510528379/02-Literasi-Digital-dalam-Perspektif-Kristen, “Pesan Perdamaian Melalui Literasi Digital" (n.d.).

${ }^{2}$ Bandura Albert, "Sisial Learning Theory, N.J.Marison," no. general learning press (1977).
} 
Keyword:

Keteladanan,pengamatan,pengalam,pengaruh

\section{A.Latar Belakang}

Perkembangan Teknologi komunikasi sekarang ini sanagat berkembang pesat. Dimana informasi-informasi sebagian besar didapat dari teknologi.khususnya dalam bidang ilmu pengetahuan dan teknologi saat ini. Sebab segalah berita sekarang atau informasi sebagian besar dipublikkan oleh berbagai orang,dan dapat di ketahui oleh seluruh dunia.dan kemungkinan mengambil bagian yang positif dan negatife bagi orang dan bahkan dengan cepat menyebar.

Melihat situasi sekarnag ini banyak orang yang menyalah gunakan teknologi tersebut,bahkan digunakan dengan tidak sesuai dalam mendapat hal-hal yang negatife yang dapat merusak karakter manusia. Seperti menggunakan teknologi dalam hal-hal yang tidak baik misalnya,seks bebas, pornografi ,kekerasan dan perjudian dll. Informasi seperti ini tidak hanya di sebarkan dengan tulisan saja tapih bahkan dengan gambar atau video sekaligus yang tidak pantas di nonton oleh kalangan orang terkhusus bagi anak-anak yang masi di bahwa umur. Karena mereka rentan ingin mencoba dan meniruh apa yang mereka tonton itu.

Dimasa sekarang ini kita harus lebih berhati-hati dan lebih berhikmat dalam menggunakan teknologi dengan baik.faktanya bahwa yang di kuatirkan dalam masa sekarang ini adalah orangorang yang penting dalam hidup kita seperti anak,karena mereka belum tau betul apa yang mereka lihat sehinggah mereka melakukan hal-hal yang mereka tonton atau liat itu. Maka dalam hal ini orang tua lebih berperan penting dalam hal ini. Orang tua harus lebih berhati-hati dan terus memntau anak-anak dalam menggunakan teknologi dan orang tua juga lebih berperan dalam pembetukan karakter anak. Namau dimasa sekarang ini remaja atau orang dewasa bahkan mereka yang banyak menyalah gunakan teknologi tersebut. Kita sebagai orang dewasa harus lebih berhatihati dalam menggunakan teknologi dan lebih berhikmat dalam menggunakan teknologi tersebut.

Pada saat ini Pendidikan lebih penting dalam membantu orang tua dalam pembentukan karakter anak,karena dengan anak berpendidikan dan mendapat ilmu di sekolah maka hal tersebuat yang dapat membantu agar anak atau orang dewasa tidak salah dalam 
teknologi,dengan itu mereka akan lebih berhati-hati dalam menggunakan teknologi dan menguakan dengan baik. Dimana orang yang mendapat Pendidikan di sekolah akan lebih mudah mengerti dan memahami sedikit fungsi dari teknologi itu

\section{Perkembangan Teknologi di masa sekarang ini dalam membentuk karakter dan dampak positir dan negetaf yang didapat dari penggunaan teknologi.}

perkembangan teknologi dimasa Sekaran ini memang membawa pada hal positif namun juga ada sisi negatifnya.dimana pada masa ini kita dibatasi dalam bertemu langsung karna adanya Covid-19 namaun dengan adanya teknologi lebih membantu kita contohnya membantu kita dalam masa Pendidikan kita sekarang ini,karena situasi sehinggah kita menggunakan teknologi dalam masa belajar atau Pendidikan seperti belajar online. Dengan adanya teknologi sehinggah membantu para murid dan guru dalam melakukan pembelajaran. Dan juga teknologi membantu kita dengan muda dalam berinteraksi dan berkomunikasi orang lain bahkan keseluru dunia sekali pun. Dengan kecanggihan teknologi komunikasi atau media social telah membantu kita semua dalam berbagai kebutuhan. Faktanya bahwa tidak bisa di pungkiri bahwa karakter atau perilaku anak hingga dewasa sering ditiruh oleh anak yang masi kecil karena penasaran sehinggah ketika melihat hal-hal di media social mereka dengan cepat melakukan bahkan meniru hal tersebut ketika melihatnya.semakin sering mereka menonton dan melihat hal-hal tersebut semakin besar kemungkinan mereka akan kecanduan dengan hal itu sehinggah merusak karakter anak.faktor tentang penting peran orang tua dalam mengawasi anak dan mendidik anak agar mengunakan teknologi dengan baik sehinggah tidak merusak karakter anak. Dalam hal ini orang mudah dan dewasa juga berperan dalam membantu orang tuanya dalam pembentukan karakter yang baik bagi anak yang masi di bawah umur. Namau sebaliknya Dalam hal ini anak muda atau dewasa sering mereka yang menyalah gunakan dan tidak berhikmat dalam mengunakan teknologi tersebut. Mereka cenderung melakukan hal-hal yang tidak baik seperti criminal,kekerasan bahkan mereka lebih tidak sopan ,dan bahkan menggunakan obat-obat terlarang yang dapat merusak mental mereka dan masi banyak lagi yang sering didapat dari penyalah gunaan teknologi. ${ }^{3}$

Dampak positif dari penggunaan Teknologi atau media sosial;

1. Memudakan kita dalam berinteraksi dengan dengan banyak orang.

2. Memperluas pergaulan .

\footnotetext{
${ }^{3}$ Https://www.scribd.com/document/510528379/02-Literasi-Digital-dalam-Perspektif-Kristen, “Pesan Perdamaian Melalui Literasi Digital."
} 
3. Lebih mudah dalam mengekspresikan diri.

4. Penyebaran informasi dapat berlangsung secara cepat.

5. Biaya lebih murah dan mudah.

Dampak negatif dari penggunaan teknologi atau media social;

1) Menjauhkan orang-orang yang sudah dekat dan sebaliknya .

2) Interaksi secara tatap muka cenderung menurun .

3) Membuat orang-orang menjadi canduan terhadap teknologi atau media social.

4) Menimbulkan konflik dan masalah privasi.

5) Rentan terhadap pengaru buruk orang lain.

Namaun bukan cuman hanya media social yang yang dapat merusak karakter kita namun juga dalam pergaulan kita atau keseharian yang buruk kita adalah salah satu hal yang bisa merusak karakter kita untuk cenderung menjerumuskan kita ke hal-hal yang tidak baik.

\section{Pentingnya Pendidikan yang didapat di sekolah dalam membantuh agar anak tidak menyalah gunakan teknologi dimasa pandemi Covid-19}

Pentingnya mendirikan sekolah karena di situ anak dia jarkan bagaiman dan seperti apa Pendidikan. Pendidikan di sekolah sangat membantu orang tua dalam mendidik anak-anak mereka,dengan adanya Pendidikan formal di sekolah di situ anak mempelajari tentang bagaiman menggunakan teknologi dengan baik,dengan demikian kepercayaan orang tua kepada guru-guru yang mendidik anak nya di percayakan penuh. Karena itu guru adalah metode atau teladan yang baik dan penting bahkan ampu bagi murid-muridnya. Bahkan ketika kita melihat situasi sekarang faktor-faktor yang timbul atau mempengaruhi anak sebagian besar dari guru.kecenderungan hati seorang guru yang sabar dalam mendidik anak-anak mulai dari anak mengenal huruf,anagka bahkan membaca sekali pun itu sebagian besar didapat di sekolah-sekolah. Dengan sabar dan niat guru-guru mendidik murid-murid. Maka dengan sadar murid akan mengetahui bagiaman pentingnya dalam mencari Pendidikan di sekolah, karena Pendidikan yang didapat di keluarga ,dilingkungan belum lengkap ketika kita belum mendapat pendidkan disekolah. Dan di lingkungan sekolah juga anak memungkingkan dan mampu menuangkan kreatifitas dan sanggup memainkan potensinya dengan apa yang didapat di sekolah ${ }^{4}$.

\footnotetext{
${ }^{4}$ Exemplary, "Menemukan Kunci Pendidikan Kristen Bagi Anak Dalam Keluarga Pembelajaran Agama Disekolah" (n.d.).
} 
Namun dari itu melihat situasi sekarang kita dalam masa pandemi Covid-19 sebagian pembelajaran dilakukan dengan menggunakan alat teknologi atau media social dalam melangsungkan proses pembelajarn yang sebagian hanya di lakukan dirumah. Dalam masa situasi sekarang ini Guru dan prang tua harus sama-sama berperan,karena guru dan orang tua harus terus membimbing anak-anak atau bahkan orang dewasa dalam bagaiman cara yang tepat dalam menggunakan teknologi tersebut. Walaupun sanagat sulit di pungkiri untuk anak atau bahkan orang dewasa sekali pun menyalagunakan alat tersebut.tapi bagaiman guru serta orang tua tetap mengajar kan hal-hal yang biak dan cara menggunakan teknologi itu. Bagaimana anak bisa mengerti dan berhikmat dalam menggunakan alat teknologi atau media social itu.Jadi dengan mengajarkan disekolah untuk bagaiama seorang anak yang berpendidikan utuk tidak menyagunakan. Disini tugas guru sangat penting dan berjasa. Walaupun dalam situasi anak sebagian lebih cenderung mengikuti perkembangan zaman namun itu wajar tapi bagaiman anak tetap bisa mengotriol diri mereka.

Bahkan di toraja sekali pun anak yang masi di bawa umur sudaha menggunakan alat teknologi di masa tradisional tersebut pada saat ini.bahkan anak yang tidak melakukan Pendidikan di sekolah tau menggunakan alat tersebut karena perkembangan industry tradisional. ${ }^{5}$

\section{Menyikapi perkembangan teknologi media sosial terhadap karakter anak}

Dimasa sekarang ini internet yang semakin terbuka di zaman sekarang ini sangat mempengaruhi karakter anak. Dimana anak sebagai generasi penerus masyarakat dan juga bangsa. Sampai kapan pun keluarga akan tetap menjadi pusat sentral dalam membentuk pola perilaku anak. Karena dari keluarga pertama kali anak mendapat Pendidikan dengan cara praktiks dan konteks keluarga adalah tempat yang baik dalam mendidik karakter seorang anak. Pendidikan di sekolah membantu anak. ${ }^{6}$

Adapun faktor yang kadang kalah mempengaruhi anak melakukan hal yang tidak baik:

1) Jangan terlalu menekang atau mempersempit pergaulan anak

\footnotetext{
${ }^{5}$ Https://www.scribd.com/document/510528379/02-Literasi-Digital-dalam-Perspektif-Kristen, "Pesan Perdamaian Melalui Literasi Digital."

${ }^{6}$ Kalis Stevanus, "Relevansi Supremasi Kristus Bagi Pemberitaan Injil Di Indonesia," KAMASEAN: Jurnal Teologi Kristen 2, no. 1 (2021): 32-46.
} 
Karena anak membutukan pergaulan juga tapi tugas orang tua tetap memantau bagaiman pergaulan anak. Karena kapan seorang anak di batasi pergaulanya kadang kalah ini yang menyebabkan merka menggunakan salah media social ketika anak dilarang bersosialisasi dengan teman-temanya.

2) Berikan pedoman atau menegur anak dalam pergaulan yang salah

Seorang anak harus sedikit di berikan kebebasan dalam pergaulan selagi itu masi bersifat positif.asal orang tua tetap mengingatkan bagaiaman pergaulan yang sesungguhnya dan tetap terus mengawasai anaknya dalam 24 jam. Penguasaan diri atau control diri adalah pengendalian dan tindakan agar anak tetap mendapat dorongan dari orang tua dan mampu mengplikasikan diluar sehinggah dapat bertindak dengan benar ${ }^{7}$.

Dalam pembentukan karakter anak sebaiknya anak jangn terlaluh di kekang sebab itu adalah salah satu hal yang dapat menjerumuskan anak melakukan hal-hal yang tidak baik. Dengan terus orang tua harus tetap mendidik anak bagaiman menggunakan alat teknologi dengan baik sehingga anak tidak keliru.

7 Https://www.scribd.com/document/510528379/02-Literasi-Digital-dalam-Perspektif-Kristen, "Pesan Perdamaian Melalui Literasi Digital." 


\section{DAFTAR PUSTAKA}

Albert, Bandura. "Sisial Learning Theory, N.J.Marison," no. general learning press (1977).

Exemplary. "Menemukan Kunci Pendidikan Kristen Bagi Anak Dalam Keluarga Pembelajaran Agama Disekolah" (n.d.).

Https://www.scribd.com/document/510528379/02-Literasi-Digital-dalam-Perspektif-Kristen. "Pesan Perdamaian Melalui Literasi Digital" (n.d.).

Stevanus, Kalis. "Relevansi Supremasi Kristus Bagi Pemberitaan Injil Di Indonesia." KAMASEAN: Jurnal Teologi Kristen 2, no. 1 (2021): 32-46. 
(2) 